Studinska Galyna, Doctor of Sciences (Economics), Associate Prof., Kyiv National University of Trade and Economics (Ukraine) ORCID: 0000-0003-4713-4957, Researcher IDS-3220-2018

\title{
BRAND AS A PHILOSOPHY OF BUSINESS IN CONDITIONS GEOECONOMIC SHIFTS
}

The systematic approach to researching the philosophy of the branding is proposed. The rational and irrational components of the branding are analyzed. Rationality of the branding is substantiated through: a description of human activity and its knowledge; modern characteristics of the world market of goods and services in general; a universal category that encompassing logic and dialectic. Irrationality of the branding is defined as a characteristic of a methodology or rules of activity that forms the economic behavior of its consumers. The essence of the branding in the light of philosophical laws is revealed: "Forms and content», "Negation of the negation», "Dynamic equilibrium». The branding is grounded as an instrument for changing the economic behavior of consumers.

Keywords: branding, branding philosophy, rationality and irrationality of the brand.

\section{Студінська Галина. Бренд як філософія бізнесу в умовах геоеконо- мічних зрушень.}

Анотація. Запропоновано системний підхід щзодо дослідження філософії брендингу. Проаналізовано раціональні та ірращіональні складові брендингу. Раціональність брендингу обтрунтовано через характеристику діяльності людини та ї̈ знання; сучасну характеристику світового ринку товарів та послуг в цілому; універсальну категорію, що охоплюе логіку та діалектику. Іррачіональність брендингу визначено як характеристику методології або правил діяльності, що формує економічну поведінку його споживачів. Розкрито суть брендингу в світлі філософських законів: "Форми та змісту», «Заперечення заперечення», «Динамічної рівноваги». Обтрунтовано брендинг як інструмент зміни економічної поведінки споживачів.

Ключові слова: брендинг, філософія брендингу, раціональність та ірраціональність бренду. 
Relevance of research topic. The dynamism of modern geopolitical processes requires economic actors and countries to respond quickly to external challenges, to increase the competitiveness of the world market for goods and services. The branding, as a phenomenon that has inherent transparency, durability, reliability, efficiency, has been widely recognized by theorists and used by practitioners. Brand as a carrier of unique qualities of goods, services, and the attractiveness of companies and organizations, individual territories and people today forms the modern philosophy of production and consumption; is considered as an effective tool for the development of the national economy, a successful strategy for increasing the competitiveness of individual subjects of the domestic economy and the national economy as a whole due to increased exports of national products, investment attraction, highly skilled labor, high technologies [2, p.77]. The research of the philosophical basis of the branding contributes to a deep understanding of this phenomenon, which determines the relevance and novelty of the chosen theme.

Formulation of the problem. The philosophy of economics is knowledge of the essence of human being's economic existence in the context of multi-vector shifts, combining logical and historical approaches to the study of economic theory; ensures penetration into the intrinsic nature of economic phenomena and processes; can justify the reasons for establishing links between these phenomena and processes; demonstrates the horizons of their further development; explains the logic and sequence of economic trends in the historical context.Awareness of the objectivity of economic laws by business entities opens up ways to increase the competitiveness of Ukrainian companies and their products and services, as well as innovative opportunities for the formation of a modern model of the national economy.

Problem statement. Explore the branding in four philosophical aspects: 1. Philosophy of branding as a process; 2. Philosophy as the basic theory of the branding (subordination to the laws of philosophy); 3 . The branding as a philosophy of management (rationality of behavior); 4. The branding as a tool for managing consumer economic behavior (irrational component of the branding).

Analysis of recent research and publications. The first direction, defined in the formulation of the problem, is sufficiently investigated by well-known brendologists, in particular J.-N. Kapferer, D. Aaker, and K. L. Keller, who use the philosophy as a system of guidelines for the branding on the construction of commercial brands (goods, services, companies). Other directions of branding philosophy are poorly researched, which makes the topic attractive for our investigation.

Presentation of the main material. The brand, as an economic phenomenon, is considered by us as a philosophy of modern business, on the one hand, understanding and application of which to various branding objects (goods, services, companies, organizations, networks, events, persons, communities, territories, t. etc.) provides the efficiency and competitiveness of the objects, but on the other hand, it needs its own philosophy of creation, development, management of brands, which, in 
essence, prompts other people to act in accordance with their goals. The philosophy of the branding as the system of guiding principles which form the basis of action of people, companies, objects and subjects of management must be well-known, understandable and convincing.

Branding, as a process of creating and developing brands of various objects, obeys the basic laws of philosophy, in particular::

1) In the context of the Law «Form and Content», a successful brand is a it is a claimed concept of the product, a clear essence, attractive to the target audience, a conscious identification and a consistent set of features and qualities consistent with each other, an accurate niche positioning, a successful name that reflects and supports the essence of the brand, visual aesthetics that is unique and adequate to the brand content. Ignoring the need in accordance with content and form leads to negative consequences: from reducing the profitability of the brand to its disappearance in general;

2) In the light of the «Negation of the negation» law, the creation and development of the brand collapses into separate, relatively independent stages, with each subsequent stage associated with the previous denial - a necessary, essential element of development, that is, the brand is inherent in the permanence and spiral of development, which affects its ramified architecture, the increase of its wealth, the periodic adjustment of external identification in line with the updating of consumer expectations;

3) In accordance with the law «Dynamic equilibrium», the current development of branding in the world causes natural chain reactions, aimed, on the one hand, on the fetishization of branding objects, causes painful psychological and physical dependence on brands, and, on the other hand, creates the effect of counteraction, neutralizing the changes that the brand provides due to socio-economic problems in society and the subjective nature of associative perception of consumers [2, p. 27].

Brand as an institution for the economic development of commercial and noncommercial objects is a prerequisite for rational and irrational behavior of consumers. The irrational behavior of the consumer is formed under the emotional and mental influence of the brand, which allows him to formulate his subsequent decisions; the rational part is formed under its economic and functional influence through the informatization and training of the consumer, the consumer's understanding of the rational advantages of the brand. The combination of conscious and subconscious consumer behavior, reproduced through the rational and irrational components of the brand, forms its maximum satisfaction, which involves emotional, spiritual, mental and economic components.

Rationality and irrationality as philosophical categories are considered in this context as an additional characteristic of the brand, which covers certain mechanisms of implementing the impact of brands on consumers at all levels of national economic competitiveness, as detailed in [3, p. 69].

The brand's rationality needs to be understood in several respects: 
1. As a characteristic of human activity. After all, the brand, above all, is the result of purposeful actions of man, from his design, projecting to creation, development and promotion. It is important not only the quality, but also the sequence of these actions. It is considered unrational to create any object prior to its design, since the latter allows you to predict all components of an object, to lay certain its properties, to take into account a set of possible deviations, to provide mechanisms for their elimination, that is, to optimize the formation process. Particularly high risks inherent in the process of creating a national brand of the country. S. Anholt accurately compares the national brand of a country with a tanker who «needs 5 miles to change course and 8 miles to stop» [1, p. 183]. Construction of each brand, including and the national brand of the country must begin with the search for the essence, the definition of mission, philosophy, platform and strategy to promote branding in the global space, which is actually the subject of research by many scholars. This is a long-lasting, troublesome, costly process that should precede the creation of external identifiers for the country's national brand. Instead, in Ukraine, the national brand has not actually been formed, and there are already three levels of external identification. Mistakes of Ukrainian branding are considered in [4, c. 34].

2. As a characteristic of knowledge. The brand's rationality is manifested in the conscious search for consumers by functional, economic benefits through the ability to know, compare and make choices. Brand helps a person in search of rationality, he acts as an educational tool that spreads knowledge, educates consumers to certain new skills, contributes to scientific and technological progress.

3. As a modern feature of the global market for goods and services in general. The brand's rationality is evidenced by the current trends in the world market for goods and services - by 2018, the cost of the most expensive brand, AMAZON, according to Brand Finance, increased by $47 \%$ to nearly 151 billion dollars USA.

4. As a universal category embracing logic and dialectics. The brand's originality is to apply branding at all levels of the national economy, as can be seen from Table. 1 .

Table 1

List of branding objects in the hierarchy of the national economy

\begin{tabular}{|l|l|}
\hline \multicolumn{1}{|c|}{$\begin{array}{c}\text { Level of } \\
\text { hierarchy }\end{array}$} & \multicolumn{1}{c|}{ Branding objects } \\
\hline Nano level & Goods; services; events \\
\hline Micro level & Private companies; nonprofit organizations \\
\hline Mezo level & State companies; territories; local authorities \\
\hline Macro level & National: events, economics; public authorities \\
\hline Mega level & International: goods (for export), events, social networks; countries \\
\hline
\end{tabular}


Some experience in applying territorial branding in Ukraine is considered in [5, p. 195]. Investigating the rationality of the national brand, it is necessary to mention the special type of relations between man and country, which would guarantee harmony between them. Rationality of the country's brand is a conscious search for such harmony.

The irrational component of the national brand of the country manifests itself in the unconscious behavior of consumers. The irrational behavior of a person is beyond the scope of the mind, is alogical, incommensurable with rational thinking, even such as to overthrow him, but emphasizes the supremacy of the sensual start of a brand. Given the primacy of the emotional component of any brand (from product to national brand), its irrational characteristic should be used during creating a brand and be managed.

The irrational component of the branding of the country is considered as a characteristic of the methodology or rules of activity that forms the economic behavior of its consumers. In this aspect, it is necessary to divide the consumer audience of the national brand into external and internal. This need is due to diffenent goals and methods of promoting the brand in the relevant audiences. In particular, the goal of creating a country's brand for its own population is the need for citizens to be aware of their own identity as a united nation, as well as the formation of a stable public confidence in its economic policy. It is the public's confidence in the reforms that are being carried out today in Ukraine that is a sure guarantor of their successful implementation, moreover, the state of the financial and credit system of the country, the structure of its debt also depends on the level of people's trust, because personal savings can turn into a powerful financial asset that not only will stimulate the lending of the subjects of the domestic economy, but will also ensure economic independence from external loans of the country. An example of such confidence can be Japan, whose public debt exceeds GDP more than 2 times, while about $40 \%$ of the state budget expenditures is covered by the country at the expense of the issuance of securities.

The emotional state of a person affects her activity, vigor, efficiency, and, most importantly, decision-making about consumer choice, that is, shapes the economic behavior of each of us. The labor productivity of the satisfied working conditions of the worker is higher compared to other workers, the cost of a satisfied tourist during a trip to another country exceeds the costs of an unsatisfied foreigner, distrust of the population to the financial and credit system and the legal state, state authorities and local self-government cause the government of the country to external loans, which carries high risks of economic dependence of the country on external will.

Conclusion. The branding is inherent in transparency, efficiency, durability, reliability, which is why it has received broad acceptance of theorists and is widely used by practitioners to various objects: goods, services, events, companies, organizations, people, networks, communities, territories, including countries.The 
branding philosophy is considered as a system of four aspects, which determines the scientific approach of research as the newest. The first aspect regarding the use of philosophy in the design and development of brands is traditionally investigated by scientists and practitioners in connection with the existence of certain commercial interests. However, the other three aspects play a fundamental role in the deep understanding of the economic nature of the brand as a phenomenon. Subordination of the branding to the basic philosophical laws («Forms and content», «Negation of the negation», «Dynamic equilibrium») is considered as the second aspect, proving the evolutionary logic of transformation of branding into an instrument of economic development of the national economy at all its levels. The following aspect indicates the presence of a strong rational component of branding, which is substantiated by the characteristics of the activities of business entities, people and their knowledge; a modern feature of the global market for goods and services in general, a universal category embracing logic and dialectics. The last aspect concerns the irrational content of the branding, which affects the change in the economic behavior of a wide range of consumers and determines trends in the development of the world economy as a whole.

\section{REFERENCES}

1. Ankhol't S. Brending: doroga k mirovomu rynku [Branding: the road to the global marke] / Saymon Ankhol't. M.: Kudits-Obraz. 2004. 270 s.

2. Studinska G. Five Secrets of the success of branding economy, 2019. Riga, Latvia: LAMBERT Academic Publishing. 157 p.

3. Studinska H., Romanuk S. Brand of the country like a form of state administration / H. Studinska, S. Romanuk // Baltic Journal of Economic Studies ed., 2017. Vol. 3, Riga, Latvia: «Baltija Publishing». P. 69-74.

4. Studins'ka G. Instytutsiyni pomylky v ukrayins'kiy praktytsi brenduvannya krayiny [Institutional mistakes in the Ukrainian practice of country branding]. V Mizhnarodniy naukovo-praktychniy konferentsiyi [«Ekonomichne zrostannya: stratehiya, napryamy i priorytety»], (Skhidnoukrayins'kyy instytut ekonomiky ta upravlinnya, m. Zaporizhzhya, 26 sichnya 2019 roku). S. 30-34.

5. Studinska G. Ya. Brand of country as a potential for sustainable development of Ukraine, 2015. Vol. 1. Sumy, Ukraine: Marketing and Innovation Management. P. 187-202. 